Research Article

\title{
Climatology and Teleconnections of Mesoscale Convective Systems in an Andean Basin in Southern Ecuador: The Case of the Paute Basin
}

\author{
Lenin Campozano iD, ${ }^{1,2,3}$ Katja Trachte, ${ }^{4}$ Rolando Célleri, ${ }^{1,2}$ Esteban Samaniego, ${ }^{1,2}$ \\ Joerg Bendix, ${ }^{4}$ Cristóbal Albuja $\mathbb{1}^{1},{ }^{1,2}$ and John F. Mejia ${ }^{5}$ \\ ${ }^{1}$ Departamento de Recursos Hídricos y Ciencias Ambientales, Universidad de Cuenca, Cuenca, Ecuador \\ ${ }^{2}$ Facultad de Ingeniería, Universidad de Cuenca, Cuenca, Ecuador \\ ${ }^{3}$ Depto. de Ingeniería Civil y Ambiental, Escuela Politecnica Nacional, Quito, Ecuador \\ ${ }^{4}$ Laboratory for Climatology and Remote Sensing (LCRS), Faculty of Geography, Philipps-University Marburg, \\ Deutschhausstraße 10, 35032 Marburg, Germany \\ ${ }^{5}$ Department of Atmospheric Sciences, Desert Research Institute, Reno, NV, USA
}

Correspondence should be addressed to Lenin Campozano; lenin.campozano@epn.edu.ec

Received 31 January 2018; Revised 30 April 2018; Accepted 23 May 2018; Published 25 July 2018

Academic Editor: Efthymios I. Nikolopoulos

Copyright (c) 2018 Lenin Campozano et al. This is an open access article distributed under the Creative Commons Attribution License, which permits unrestricted use, distribution, and reproduction in any medium, provided the original work is properly cited.

\begin{abstract}
Mesoscale convective systems (MCSs) climatology, the thermodynamic and dynamical variables, and teleconnections influencing MCSs development are assessed for the Paute basin (PB) in the Ecuadorian Andes from 2000 to 2009. The seasonality of MCSs occurrence shows a bimodal pattern, with higher occurrence during March-April (MA) and October-November (ON), analogous to the regional rainfall seasonality. The diurnal cycle of MCSs shows a clear nocturnal occurrence, especially during the MA and ON periods. Interestingly, despite the higher occurrence of MCSs during the rainy seasons, the monthly size relative frequency remains fairly constant throughout the year. On the east of the $\mathrm{PB}$, the persistent high convective available potential and low convective inhibition values from midday to nighttime are likely related to the nocturnal development of the MCSs. A significant positive correlation between the MCSs occurrence to the west of the PB and the Trans-Niño index was found, suggesting that ENSO is an important source of interannual variability of MCSs frequency with increasing development of MCSs during warm ENSO phases. On the east of the PB, the variability of MCSs is positively correlated to the tropical Atlantic sea surface temperature anomalies south of the equator, due to the variability of the Atlantic subtropical anticyclone, showing main departures from this relation when anomalous conditions occur in the tropical Pacific due to ENSO.
\end{abstract}

\section{Introduction}

Precipitation in tropical South America (TSA) is modulated by the spatial oscillation of the intertropical convergence zone (ITCZ), and an important fraction of this precipitation is generated by organized convection in the form of mesoscale convective systems (MCSs) [1-3]. MCSs are defined as groups of organized convective storms lasting at least 3 hours [4], producing high rates of precipitation, which enhance the likelihood of flooding [5]. MCSs have also been linked to flash floods and rainfall-induced landslides [6], negatively impacting the infrastructure and socioeconomic welfare. The interaction of the prevailing air flow with the eastern inter-Andean region triggers convection and the development of MCSs. In summary, MCS-related precipitation impacts the regional distribution of water, the infrastructure and management of water resources, and the use of water by humans and ecosystems.

The climate in Ecuador presents a high spatiotemporal variability. For instance, the Andes cordillera in Ecuador acts as a weather divide [7], which also modulates precipitation regimes and seasonality. In the coastal region on the west side of the Andes range, precipitation is influenced by the ITCZ, with one rainy season peaking between December and 
May and the South Pacific anticyclone inhibiting precipitation during the second half of the year [7]. The Pacific Ocean sea surface temperature, especially over the Niño $1+2$ region, and the Southeast Pacific anticyclone have been related to interannual variability of temperature and rainfall in this region mostly related to El Niño-Southern Oscillation (ENSO) [7]. Eichler et al. [8] found that, during the warm phase of the ENSO, precipitation synoptic-scale variability during the wet season December-February (DJF) was linked to the activity of northern hemisphere extratropical cyclones. On the contrary, climate in the Amazon is mostly affected by convection activity related to the ITCZ [9] and the relatively higher humidity as well as easterly winds that produce orographic precipitation on the eastern flanks of the cordillera [10]. Therefore, the Amazon region of Ecuador is rainy along the year, with two main rainy seasons from February to May and from October to November [11]. Despite the potential impacts of the MCS on societal aspects, studies on the MCS in Ecuador are limited. Previous studies have documented the existence of katabatic cold air flows descending from the high Andean mountain region. This downslope flow encounters warm, moist air from the Amazon basin, leading to the formation of unstable convective clouds $[12,13]$. Over the foothills of the southeastern Andes in Ecuador, Bendix et al. [14] showed the occurrence of convective clouds late afternoon and the nocturnal enhancement of cell development from 1:00 to 4:00 LST during the austral summer. The late afternoon mesoscale convective complexes (MCCs) are related to typical thermal convection [14]. In the study by Bendix et al. [14], the frequency of the MCC weakens at $1 \mathrm{~h}$ and strengthens again at $4 \mathrm{~h}$, which is the second phase of MCC development (less frequent than thermal-induced MCCs). The MCCs formed on the second phase, which are related to katabatic flows, are responsible for the early morning rains [14]. As climate variability is complex in Ecuador, the variability of MCSs arises in several scales. For instance, the topographic influence is evident in the diurnal cycle of MCSs, whereas the influence of the ITCZ may be revealed in intra-annual time scales, which in turn may be modulated at intra-annual time scales for phenomena such as the 3- to 11-year quasi-oscillating ENSO.

In this paper, we study the spatial-temporal distribution of MCSs over the Paute basin, which is one of the most monitored basins in Ecuador. The Paute basin is strategically important because it harbours several important hydropower generation plants, accounting for nearly $40 \%$ of nation's hydroelectrical production. Furthermore, several cities in the region depend on the PB for their water services. Nearly $40 \%$ of the basin area is covered by páramo, a neotropical alpine wetland that occurs in the upper Andean region of Venezuela, Colombia, Ecuador, and Perú [15]. The soil-vegetation system of the páramo is considered an important water-regulating ecosystem that helps to regulate downstream water needs during the low precipitation seasons, although some authors argue that seasonal rainfall variation in these regions is low (e.g., Buytaert et al. [16]). From a scientific perspective, the $\mathrm{PB}$ is an important zone because of its complex spatial-temporal climate variability due to the complex topography $[11,17]$.
To contribute to the understanding of MCSs in the interAndean region of Southern Ecuador, the present study estimates the climatology of MCSs and their climatological thermodynamic and dynamical related variables such as the convective available potential energy (CAPE), convective inhibition (CIN), and Omega and provides an initial exploration of the most relevant teleconnections affecting interannual variability of MCS occurrence in the Paute River basin. Based on the previous research, a relationship between MCS occurrence and the seasonality of rainfall in the Paute basin is expected. As a consequence, the study of the relationship between different climate signals and precipitation, which will be called precipitation teleconnections from now on, is a key step to unravel the climatic drivers which are most relevant for MCS occurrence.

\section{Study Area}

The Andes cordillera in Ecuador stretches between $2^{\circ} \mathrm{N}$ and $5^{\circ} \mathrm{S}$ latitude and includes an inter-Andean depression with an elevation around $2500 \mathrm{~m}$ ASL, including peaks over $6000 \mathrm{~m}$ ASL (e.g., Chimborazo Glacier, $6270 \mathrm{~m}$ ASL). The complex topography, the influence of the ITCZ, and the influence of Pacific and Atlantic Ocean SST result in complex climatic spatial gradients [18]. The easterlies enhance precipitation along the windward side of the Andes (eastern slopes), which is also the case for the Paute basin (PB, an area of $\left.6481 \mathrm{~km}^{2}\right)$ [10]. In addition, in the $\mathrm{PB}$, the western cordillera is higher than the eastern cordillera sheltering the PB from the coastal plain circulation. This study is part of a larger research project aiming to study the influence of MCSs on the precipitation over the $\mathrm{PB}$, in which an area of $150 \mathrm{~km}$ radius from the Paute station $\left(2.8^{\circ} \mathrm{S}, 78.76^{\circ} \mathrm{W}, 2194 \mathrm{~m}\right.$ ASL) was designated as the study area (Figure 1). To determine the radius of $150 \mathrm{~km}$, the time resolution of GridSat data (3 hours) together with the average travel speed of clouds $(50 \mathrm{~km} / \mathrm{h})$ was considered. The selected region allows to detect MCSs that developed over (i) the PB and (ii) the coastal plains west of the PB and (iii) from the Amazon region east of the $\mathrm{PB}$.

The elevation of the PB ranges between 900 and $4200 \mathrm{~m}$ ASL. Precipitation variability in the PB can be classified into three distinctive regimes [11]. Over the inter-Andean valleys, there is a bimodal (BM) regime, related to the ITCZ passage, with the rainy months in the periods March-April and October-November. Along the eastern slopes of the eastern cordillera, the precipitation regime is rather uniform with a unimodal (UM) peak in July, coinciding with the relatively drier season of the BM regime. These regions are directly exposed to strong easterlies, bringing moist air from the Amazon during boreal summer, fostering the formation of orographic clouds and precipitation. The transition zones between the UM and BM regimes have been related to a third precipitation regime (TM) [11]. Annual precipitation in the UM regions varies between 1100 and $3400 \mathrm{~mm}$, between 660 and $1100 \mathrm{~mm}$ in the BM inter-Andean valleys, and between 1000 and $1800 \mathrm{~mm}$ in the high mountain BM regions [17]. The temperature in the Andes region of Ecuador is highly correlated with the sea surface temperature anomalies (SSTA) in the tropical Pacific in El Niño 3 


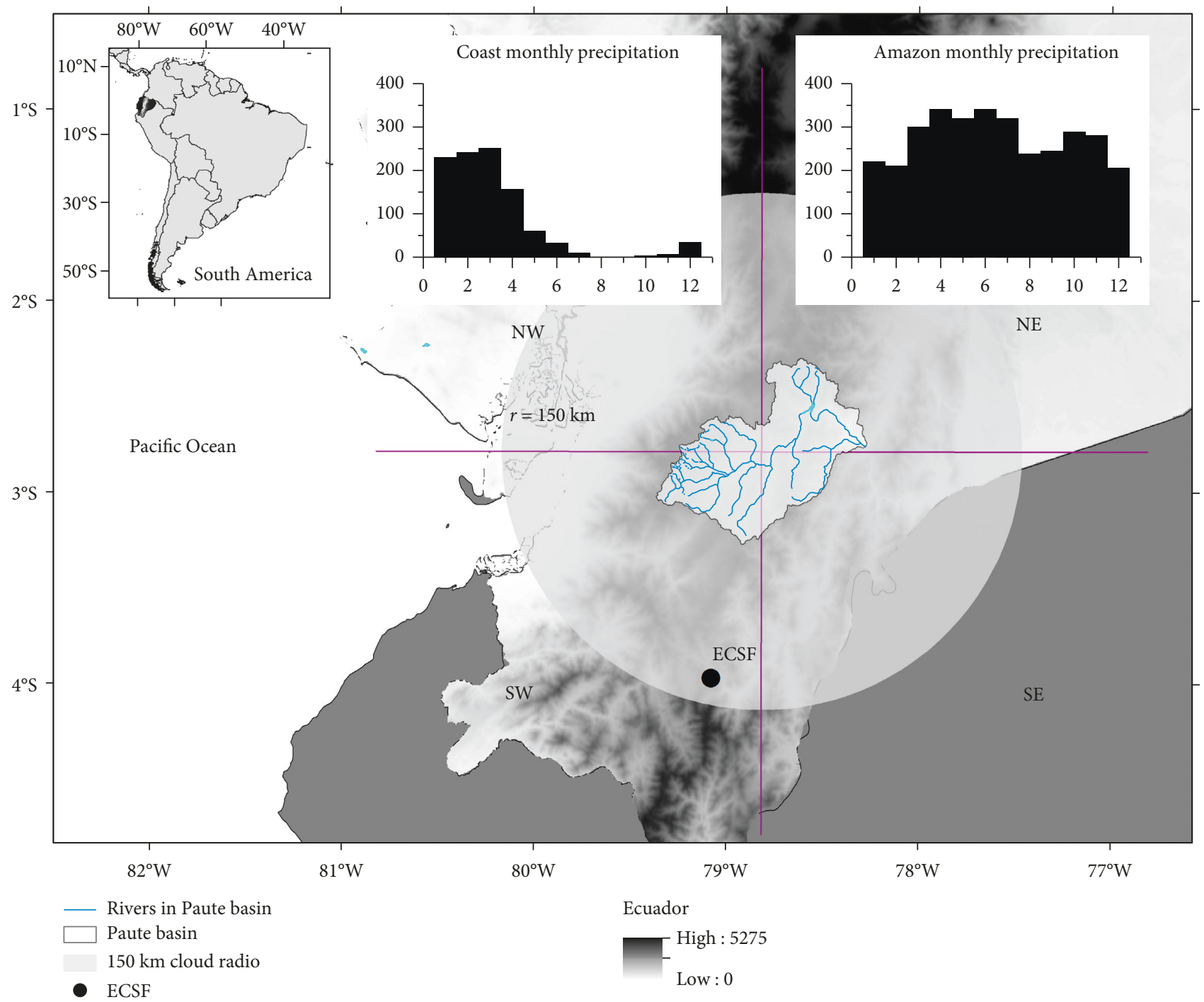

FIgure 1: The study area includes the Paute basin, $150 \mathrm{~km}$ radius around the Paute station. San Francisco scientific station (ECSF).

and 3.4 regions with a one-month lag [19]. However, in the $\mathrm{PB}$, due to the wide range of altitudinal gradients, the temperature is highly variable [17], with an average daily temperature of $6^{\circ} \mathrm{C}$ in El Labrado station, situated on the western cordillera, and $24^{\circ} \mathrm{C}$ in the inter-Andean valleys.

\section{Data}

MCS detection was based on the infrared window (IRWIN) channel (near $11 \mu \mathrm{m}$ ) brightness temperature (BRT) of the GridSat-B1 data set [20]. The GridSat-BRT data are on a latitude equal-angle grid with a 0.07 -degree spatial resolution and a spatial extent of $70^{\circ} \mathrm{N}$ to $70^{\circ} \mathrm{S}$. They are available from 01 Jan 1980 to present with a temporal resolution of 3 hours. For this study, we used the spatial subset covering $85^{\circ} \mathrm{W}$ to $69^{\circ} \mathrm{W}$ and $15^{\circ} \mathrm{S}$ to $5^{\circ} \mathrm{N}$ (Figure 2) and selected the period 01 Jan 2000 to 31 Dec 2009 which contains 29,224 images. The temporal resolution of the GridSat-B1 data certainly speaks against their use for the detection of the MCS, especially if one wants to make statements about their life cycle, for example, the study of Rehbein et al. [21] with focus on the Amazon basin in the region between $44.96^{\circ} \mathrm{S}$ and $13.68^{\circ} \mathrm{N}$ and $82.00^{\circ} \mathrm{W}$ and $32.96^{\circ} \mathrm{W}$. In this study, the occurrence of the MCS in the Paute basin is investigated; therefore, the time resolution of 3 hours of GridSat-B1 is sufficient for the spatial detection of the MCS.

For the analysis of the climatology of the thermodynamic (CAPE in $\mathrm{J} / \mathrm{kg}$ and CIN in $\mathrm{J} / \mathrm{kg}$ ) and dynamical variable Omega in $\mathrm{Pa} / \mathrm{s}$ on $2.5^{\circ} \times 2.5^{\circ}$ resolution, data were downloaded from NOAA-CIRES 20th Century Reanalysis version 2 [22] (http:// www.esrl.noaa.gov/psd/data/gridded/data.20thC_ReanV2.html). COBE-SST data in $1^{\circ} \times 1^{\circ}$ resolution were provided by the NOAA/OAR/ESRL PSD (Boulder, Colorado, USA) under https://www.esrl.noaa.gov/psd/ [23].

\section{Methods}

Features such as the cloud area maximum extent size, cloud area maximum extent time occurrence, and the geographical location were analyzed to assess the climatology of MCSs in 


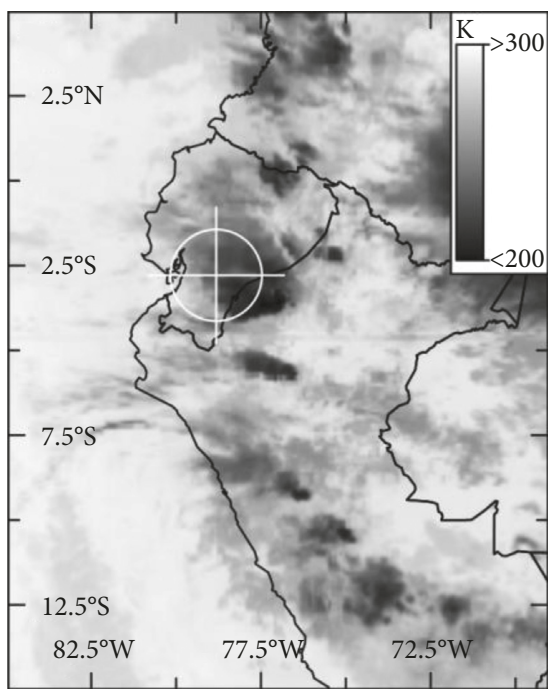

(a)

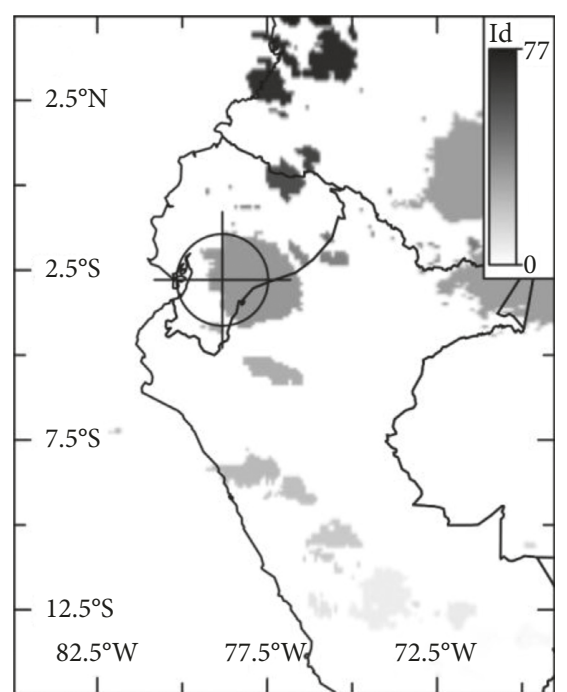

(b)

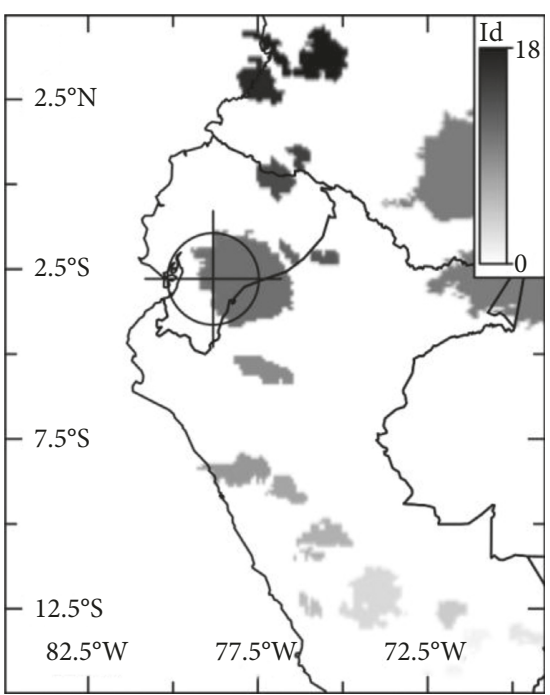

(c)

FIgURE 2: Example of image segmentation (after Bendix et al. [14]): (a) GridSat-B1 BRT at 1200 UTC 31 Mar 2009, (b) all convective entities, and (c) MCS-like entities only.

the PB. To characterize the climatology of thermodynamic and dynamical variables which may influence MCS development, the diurnal cycle of CAPE, CIN, and Omega was studied using information at 01:00, 07:00, 13:00, and 19:00 LST $($ LST Ecuador $=U T C-5 \mathrm{~h})$. Then, it was linked to the diurnal cycle of MCSs and further related to their variability during the year. To study the MCS teleconnections, the previously studied precipitation teleconnections such as SST in the Pacific and the Atlantic Ocean were evaluated. Thus, for MCSs with maximum extend on the west of the PB, towards the coastal plains, the teleconnections with tropical Pacific SST were studied [24, 25]. On the contrary, for MCSs developed on the east of the $\mathrm{PB}$, the teleconnections related to tropical Atlantic SST were studied [26].

A concise description of the different methods used is given in the following sections.

4.1. MCS Detection. For the detection of the MCS, the method presented by Bendix et al. [14] was used with slight adaptations to the specifications of this study. The BRT thresholds for the cloud shield and for active convection were set to $241 \mathrm{~K}$ and $220 \mathrm{~K}$, respectively, while the thresholds for the cloud area $\left(2000 \mathrm{~km}^{2}\right)$ and eccentricity were maintained (Figure 2). Furthermore, the maximum distance from the center of the Paute basin $\left(78.8177^{\circ} \mathrm{W}\right.$, $2.7874^{\circ} \mathrm{S}$ ) to the center of the detected cloud, here the centroid of the cloud area is meant, was set to $150 \mathrm{~km}$. For each classified MCS entity, morphological and intensity parameters are estimated, including the cloud area $\left(\mathrm{km}^{2}\right)$, the perimeter $(\mathrm{km})$, the coldest BRT of the cloud $(\mathrm{K})$, the distance to the reference point $(\mathrm{km})$, and the position in the northeast (NE), northwest (NW), southeast (SE), and southwest (SW) to the reference point, and are returned by the algorithm.
4.2. Climatology of the MCS. To study the climatology of MCSs influencing the PB, the seasonality of MCSs was first determined using box-and-whiskers plot for each month (Figure 3). Afterwards, the monthly mean number of MCSs occurring in NE, SE, NW, and SW quadrants was calculated in order to identify MCS main geographic sources of influence, which in turn may be linked to different synoptic conditions either convective or subsiding (Figure 4). Then, the diurnal cycle of MCS occurrence in the PB was evaluated by month. This was determined by calculating the average number of MCSs at its maximum extend occurring in each hour of the day on each month of the year (Figure 5). Finally, the MCS size absolute frequency and relative frequency were determined for each month. For the absolute frequency, the number of MCSs for each bin on each month was calculated. For the relative frequency, the number of MCSs for each bin on each month was divided by the total number of MCSs occurring on the respective month (Figure 6).

\subsection{Climatology of Thermodynamic and Dynamical Variables} Influencing MCS Development. Variables used for the explanation of MCS formation are CAPE, CIN, and Omega. CAPE is the maximum buoyancy of an air parcel which is related to the potential updraft strength of a thunderstorm. $\mathrm{CIN}$ is a measure of the negative buoyancy that needs to be exceeded to initiate convection. Given that mesoscale convection may be constrained by large-scale conditions, the vertical velocity in pressure coordinates (omega $(d p / d t))$ at $600 \mathrm{hPa}$ was analyzed, considering that upward (downward) air motion enhances (inhibits) convection. The monthly climatology of CAPE, CIN, and Omega (Figures 7-9, resp.) was generated for 01:00 LST, 07:00 LST, 13:00 LST, and 19:00 LST for the area between $82^{\circ} \mathrm{W}$ and $76^{\circ} \mathrm{W}$ and zonally averaged from $0^{\circ}$ to $4^{\circ} \mathrm{S}$. 


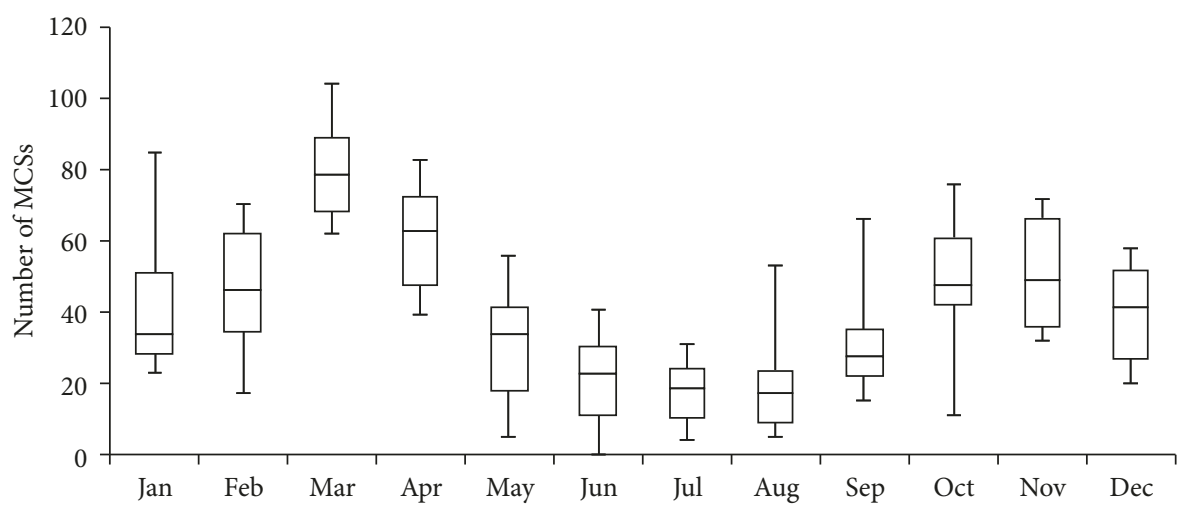

FIgURe 3: Monthly mean MCS occurrence in the Paute basin during January 2000 to December 2009.

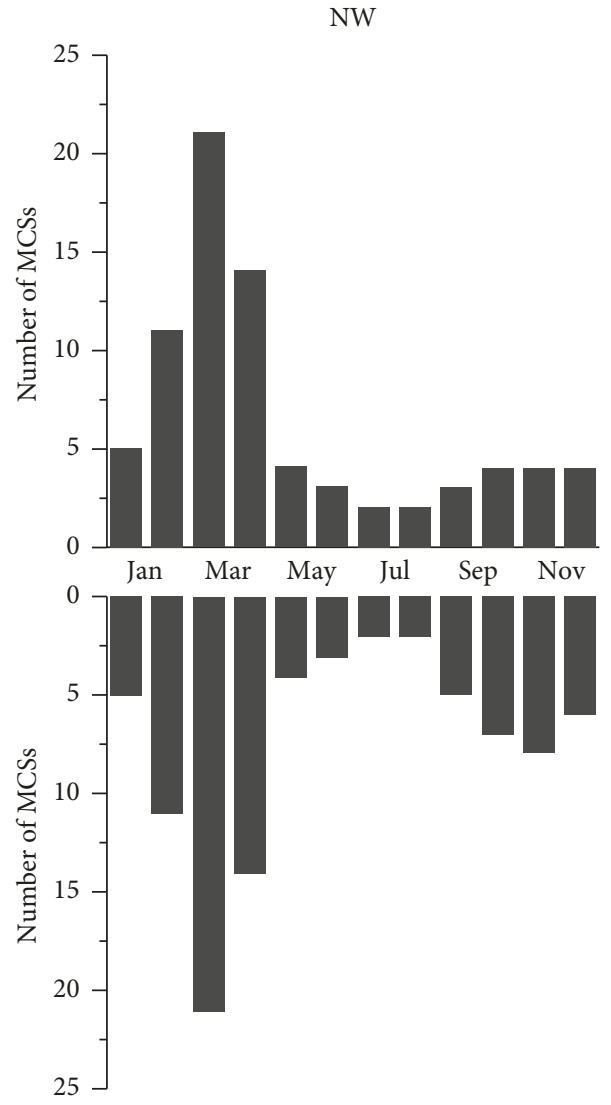

SW
NE
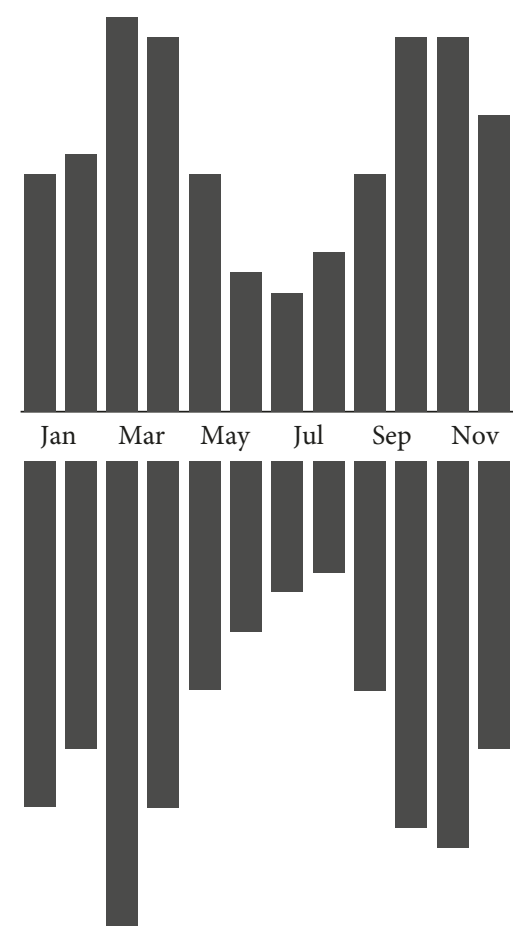

SE

FIgUre 4: Monthly mean number of MCSs in NE, SE, NW, and SW quadrants around the Paute basin.

4.4. Teleconnection Patterns and MCS Development. Precipitation teleconnections in Ecuador vary depending on the region $[24,26,27]$. For instance, precipitation in the coastal plains, west of the $\mathrm{PB}$, is related to the sea surface temperature along the tropical Pacific. The SST in the El Niño $1+2$ region was related to strong anomalies of precipitation in the coast mainly before the year 2000 [24, 26]. Campozano et al. [28], using the January-to-April cumulative TRMM precipitation estimates from 1999 to 2014, showed that the first principal component of precipitation in Ecuador is correlated to the Trans El Niño index, which is given by the difference between the normalized SST anomalies averaged in the Niño $1+2$ and Niño4 regions [29], thus measuring the gradient of anomalous SST between both regions.

The teleconnections between the cumulative area of the MCS and ENSO indices such as SST in the regions Niño $1+2$, Niño 3.4, and TNI were evaluated on the west of the PB (MCS-W). The MCS monthly time-series anomalies were obtained by removing the trend. It was achieved by using a Fourier fitting to the time series in the first place and then removing the lower frequencies. Finally, a 3-month moving average was applied. 


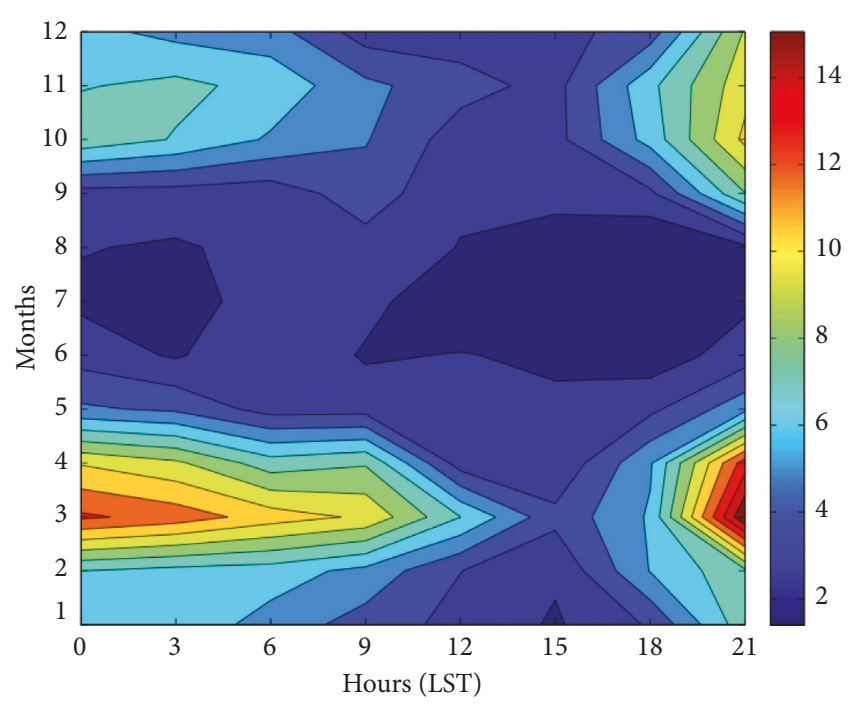

Figure 5: Monthly mean number of MCSs in the Paute basin.

The teleconnections were evaluated by correlating the MCS-normalized time series with SST Niño $1+2$, SST Niño 3.4, and TNI. To study the teleconnections of MCSs east of the PB, the approach of Vuille et al. [30] was followed. Vuille et al. [30] showed that, during most of the year, the precipitation variability along the east of the Ecuadorian Andes is positively correlated to the tropical Atlantic SST anomalies south of the intertropical convergence zone and negatively correlated to the north. On the contrary, it is well known $[24,26]$ that SST in the tropical Pacific inversely affects the precipitation in the western Amazon. Therefore, following Vuille et al. [30], Atlantic SST data from $60^{\circ} \mathrm{W}$ to $10^{\circ} \mathrm{E}$ and $30^{\circ} \mathrm{N}$ to $30^{\circ} \mathrm{S}$ monthly anomalies were obtained by subtracting the mean monthly values for the 01-2000 to 12-2009 periods. Then, the principal components of the anomalies were calculated using the library Climate Data Operators (CDO 2018: Climate Data Operators, available at: http:// www.mpimet.mpg.de/cdo). Finally, the 3-month moving average of main PC score time series was correlated with 3-month moving average normalized anomalies of MCSs on the east of the PB (MCS-E).

\section{Results and Discussion}

\subsection{Climatology of the MCS}

5.1.1. Seasonality. The multiyear annual mean of MCSs in the PB is ca. $487 \mathrm{MCSs} / \mathrm{yr}$. At the monthly scale, the monthly mean MCS occurrence in the PB is shown in Figure 3. The bimodal intra-annual variability of MCSs in the study region follows the bimodal rainfall seasonality, which is influenced by the ITCZ displacement [11]. Bendix et al. [14] showed a similar seasonality of MCS occurrence in a study conducted in the Rio San Francisco Valley, close to the ECSF meteorological station, $3^{\circ} 5^{\prime} 22^{\prime \prime} \mathrm{S}, 79^{\circ} 04^{\prime} 52^{\prime \prime} \mathrm{W}, 1957 \mathrm{~m}$ ASL, situated in the foothills of the southern Andes in Ecuador. However, their study was based on only 3 years of satellite images. Similarly, Jaramillo et al. [3] found that the

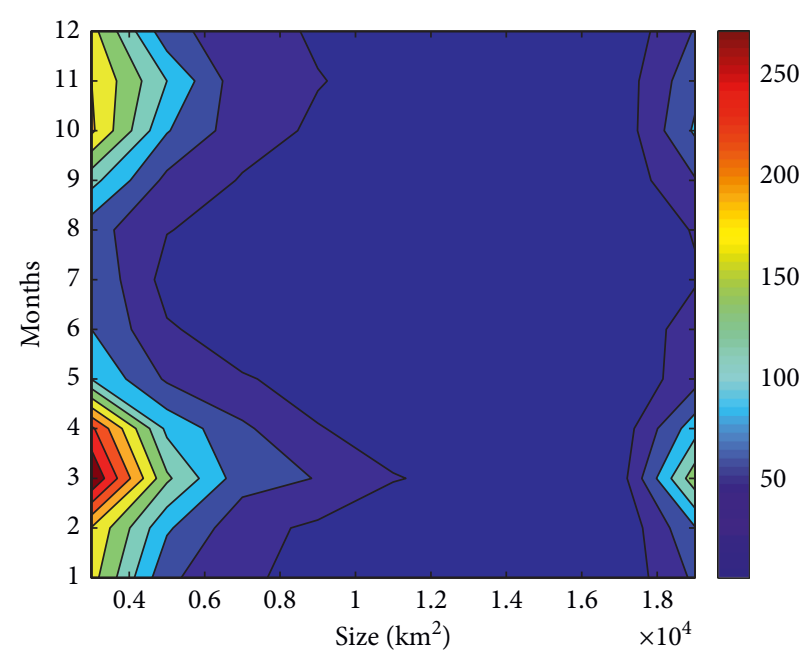

(a)

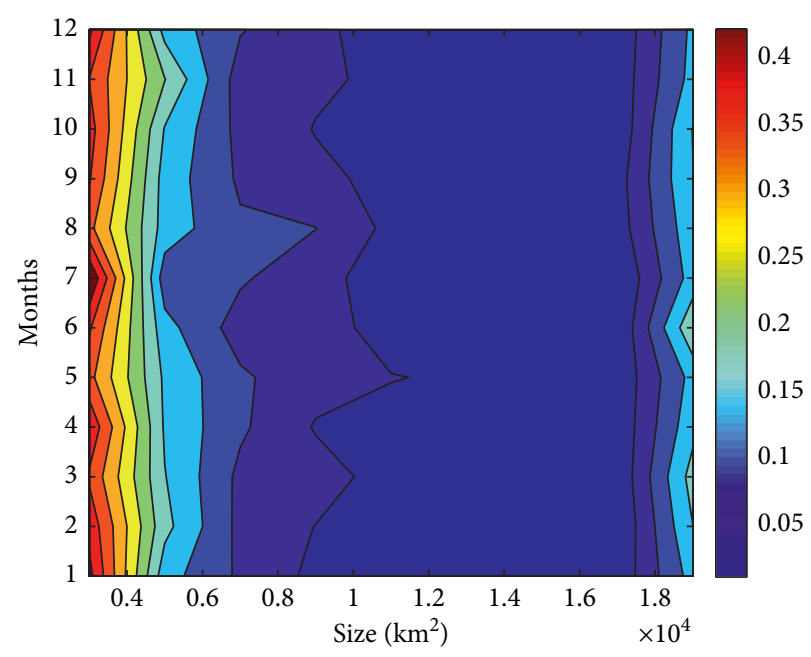

(b)

FIgURE 6: Number of MCSs by size and month (a) and monthly fraction of MCSs by size and month (b).

seasonality of MCSs is bimodal across the western Amazon using TRMM data. The results reveal that the annual course of ITCZ-related atmospheric conditions, such as atmospheric stability and changes in wind field, generally modifies the local occurrence of MCS formation.

5.1.2. MCS Geographical Location. Figure 4 shows the number of MCS occurrences per NE, SE, NW, and $S W$ quadrants around the center of the $\mathrm{PB}$. A striking feature is that the eastern quadrants present much more MCS occurrences, suggesting that MCSs coming from the Amazon and the eastern flanks of the eastern cordillera influence tend to dominate PB's convective systems. Only during February to April (wet season over the coast), the western quadrants show a similar occurrence of MCSs to the eastern quadrants. The predominance of MCSs throughout the year in the eastern quadrants (Figure 4) supports the hypothesis that precipitation in the $\mathrm{PB}$ is mainly due to the Amazon influence enhanced by the easterlies [11]. On the contrary, the 


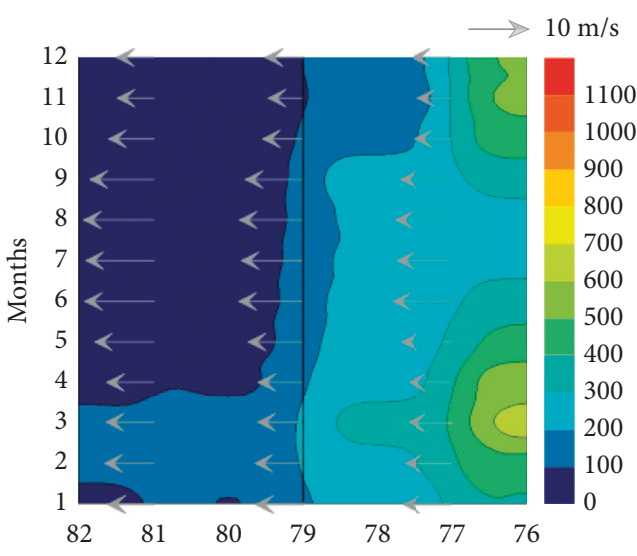

(a)

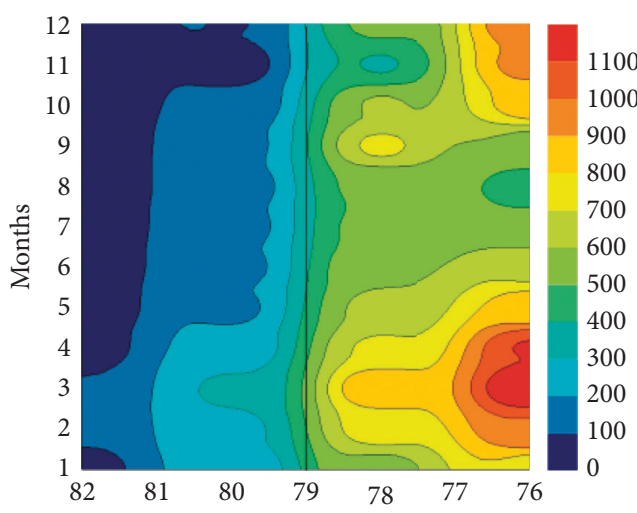

(c)

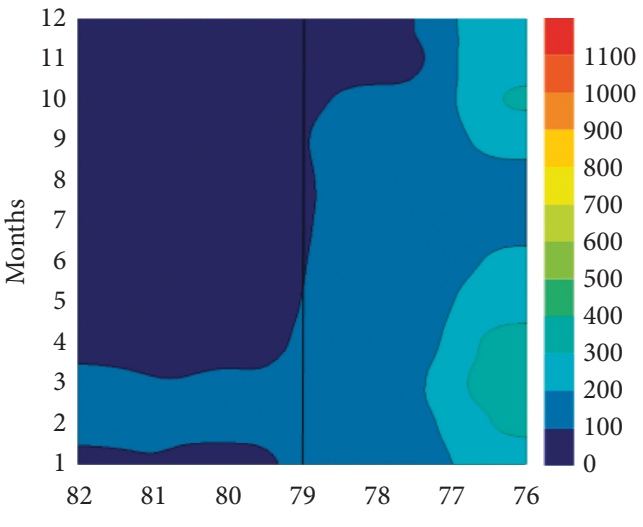

(b)

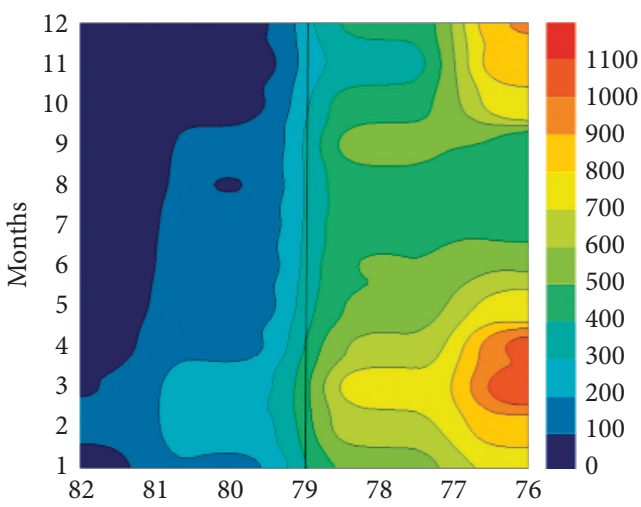

(d)

Figure 7: Monthly climatology of CAPE (J/kg) across a longitudinal transect from $82^{\circ} \mathrm{W}$ to $76^{\circ} \mathrm{W}$ averaged from the equator to $4^{\circ} \mathrm{S}$ at (a) 01:00 LST, (b) 07:00 LST, (c) 13:00 LST, and (d) 19:00 LST. The black line represents the longitudinal position of the Paute basin. In (a), arrows indicate zonal winds at $600 \mathrm{hPa}$ monthly average from 2000 to 2009.

western influence of MCSs is important for the PB, from February to April, especially in March, during the rainy season of the coastal plains. The influence of the South Pacific anticyclone, which is responsible for atmospheric stable stratification during the second half of the year in the coastal plains, suppresses MCS development in the dry season in the western quadrants of the PB.

5.1.3. Monthly Diurnal Cycle. The diurnal cycle of the MCS maximum extent averaged by month is presented in Figure 5 . It is clearly depicted that nighttime occurrence is much higher, with an occurrence peak at 00:00 LST. This fact is more evident during the rainy seasons March-April and October-November. In order to examine the factors leading to MCS development during the nighttime, further analyses of thermodynamic and dynamical variables is conducted in Section 5.2. Bendix et al. [14] found a similar nighttime occurrence of MCSs in the Rio San Francisco Valley in the southern part of Ecuador. The Rio San Francisco Valley is oriented in the southwest-northeast direction, located close to the ECSF meteorological station. Bendix et al. [14] reported a secondary maximum occurrence of MCCs from 01:00 to 04:00 LST. It is important to point out that, despite the nocturnal occurrence of MCSs, the diurnal cycle of precipitation in the inter-Andean valleys is mainly driven by the afternoon convection, with a peak around 16:00 LST [7, 11,31].

Romatschke and Houze [32] showed that, in the eastern foothills of the Andes towards the Amazon, nocturnal convective systems are more frequent than daytime convective systems. It was hypothesized that local small-scale effects, specifically nocturnal downslope winds, a result of the divergence over the mountains, lead to convection at the foothills. Indeed, Trachte et al. [13] conducted a detailed study of the development of an MCS in the Rio San Francisco Valley located in the eastern escarpments of the Andes. They proved that the interaction of the drainage katabatic flows of the Andean drainage system with the warm-moist air of the Amazon induces flow confluence causing compressional lifting, which later leads to nocturnal cloud clusters.

5.1.4. MCS's Size Distribution. Figure 6(a) shows the monthly absolute frequency per bin size. Of note is that February-April and October-November show larger MCSs on each bin size. However, the relative size distribution (Figure 6(b)) is more uniform throughout the year suggesting that, during the months with more MCSs, more repetitions of the same distribution occur. A more detailed analysis of the MCS monthly 25th, 50th, and 75th size 

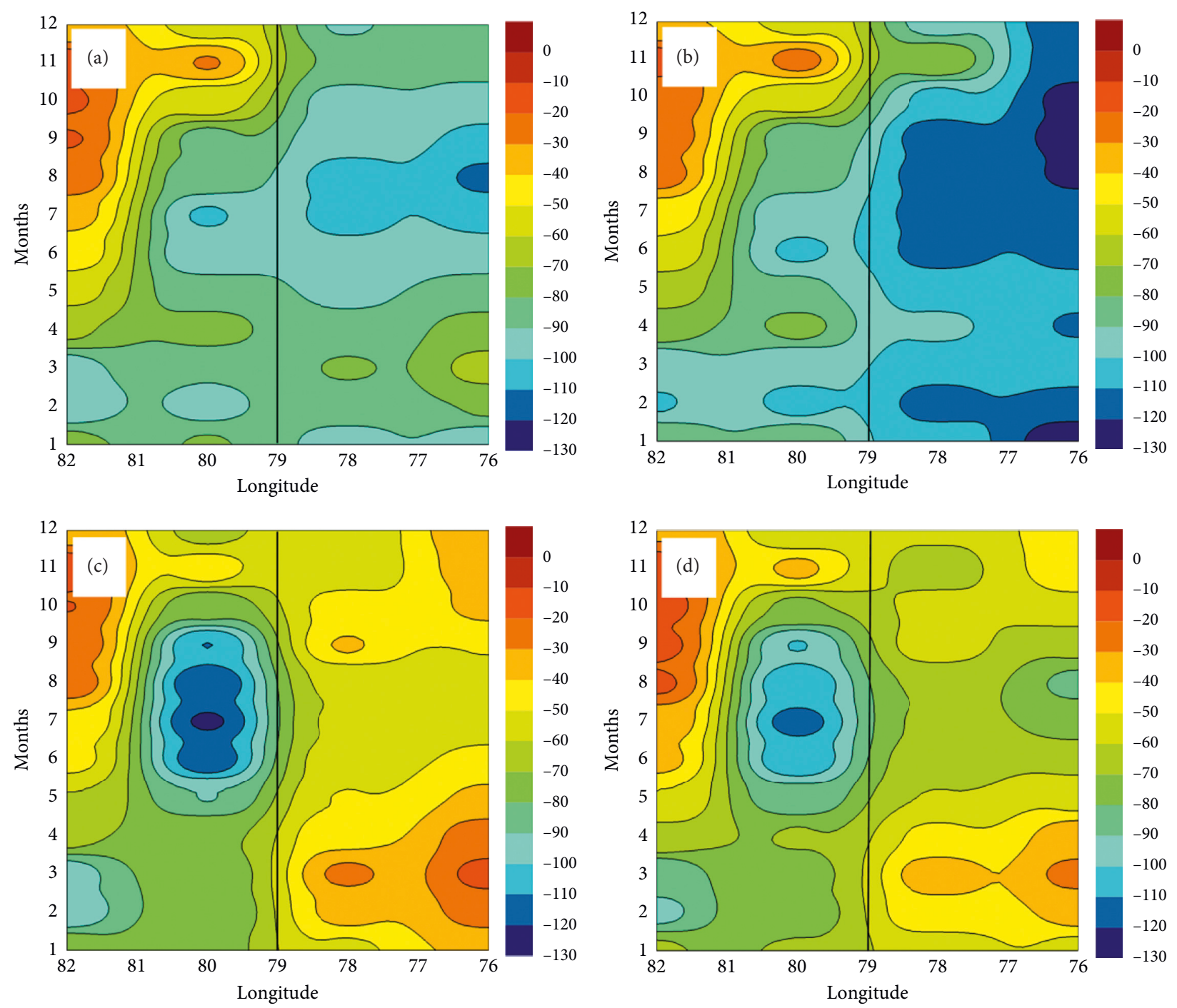

Figure 8: Monthly climatology of CIN (J/kg) across a longitudinal transect from $82^{\circ} \mathrm{W}$ to $76^{\circ} \mathrm{W}$ averaged from $0^{\circ}$ to $4^{\circ} \mathrm{S}$ at (a) $01: 00 \mathrm{LST}$, (b) 07:00 LST, (c) 13:00 LST, and (d) 19:00 LST. The black line represents the longitudinal position of the Paute basin.

percentiles is presented in Table 1 . The multiannual 25th, 50th, and 75th percentiles of the MCS's area are $2989 \mathrm{~km}^{2}$, $5063 \mathrm{~km}^{2}$, and $11,712 \mathrm{~km}^{2}$, respectively. Notwithstanding, the 25 th and 50th percentiles show a small variation throughout the year. However, the 75 th size percentile is $6 \%$ higher than the multiannual median in March and September, 19\% higher in June (largest month), and 15\% lower in December. Note that the highest 75th size percentile occurs in June. The large MCS's size is coincident with the rainy seasons February-April and October-November. The study of MCS seasonal size variation was conducted by [3] with special focus over Colombia. They found that, over the Caribbean Sea and the Pacific Ocean, MCS's size showed a small variation during the year. In contrast, the seasonal variation of MCSs over the continent was considerably large. Specifically, over the Colombian territory, Jaramillo et al. [3] showed that the largest MCSs occurred during the MarchApril season (average area $21,442 \mathrm{~km}^{2}$ ). In the Amazon region, they found that the largest MCSs tend to occur during December-February (average area $27,017 \mathrm{~km}^{2}$ ).
5.2. Climatology of CAPE, CIN, and Omega. The monthly climatology of CAPE (in J/kg), CIN (in J/kg), and Omega at 01:00 LST, 07:00 LST, 13:00 LST, and 19:00 LST was used to relate the MCS formation to the atmospheric conditions on longer terms average. The values of the CAPE are depicted in Figures $7(\mathrm{a})-7(\mathrm{~d})$. The black line in the figure depicts the longitudinal location of the PB. In general, the CAPE pattern at 01:00, 07:00, 13:00, and 19:00 LST differs between both sides of the $\mathrm{PB}$, with higher values over the eastern Amazon sectors (longitude 76W). CAPE values at 01:00 LST (Figure 7(a)) are low across the longitudinal transect, limiting the capabilities of the formation of MCSs. CAPE values at 07:00 LST (Figure 7(b)) display low values on the western and eastern sides of the $\mathrm{PB}$, suggesting that a relatively low energy for convection is available early in the morning, hindering the development of MCSs. This condition is more common during June-August, when low CAPE values are observed over the Amazon. CAPE at 13:00 LST (Figure 7(c)) shows a large longitudinal contrast of CAPE with the Andes as boundary. To the east of the Andes and into the Amazon, 

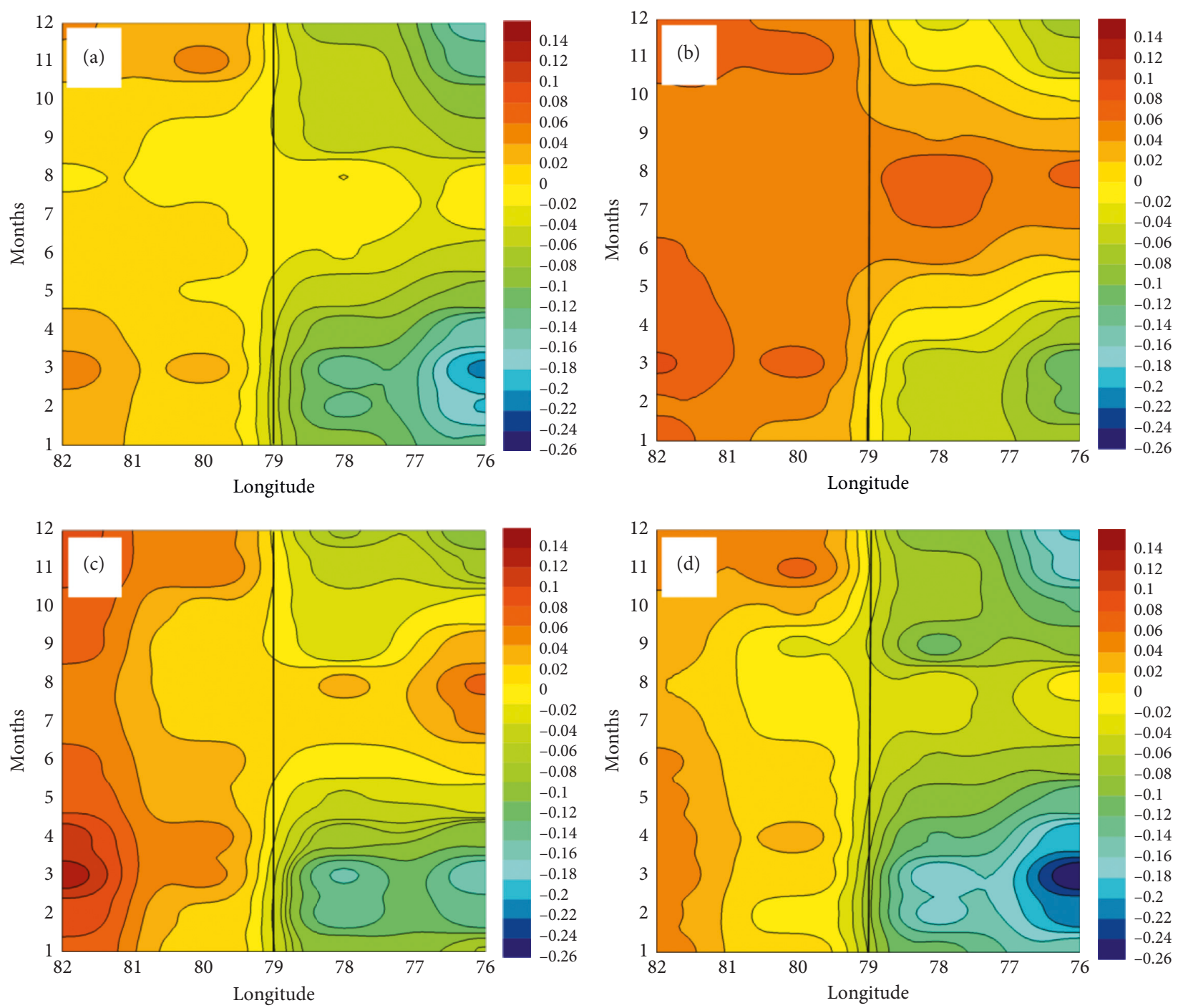

Figure 9: Monthly climatology of Omega (Pa/s) across a longitudinal transect from $82^{\circ} \mathrm{W}$ to $76^{\circ} \mathrm{W}$ averaged from $0^{\circ}$ to $4^{\circ} \mathrm{S}$ at (a) $01: 00 \mathrm{LST}$, (b) 07:00 LST, (c) 13:00 LST, and (d) 19:00 LST. The black line represents the longitudinal position of the Paute basin.

values of CAPE over $800 \mathrm{~J} / \mathrm{kg}$ are displayed from February to April, with CAPE increasing eastward. These high values of CAPE are related to the increase of MCS development during the afternoon. From June to August, CAPE reduces to around $600 \mathrm{~J} / \mathrm{kg}$, with a corresponding reduction of MCS activity in the afternoon. CAPE values increase again in September and October, when there is a corresponding increase in MCS activity. From 13:00 to 19:00 LST and over the west side of the PB, lower CAPE values are observed likely due to midlevel warm air advection from the Andes. The latter likely explains the higher occurrence of MCSs during the night, especially in the periods February to April and September to December in the Amazon region.

The monthly climatology of CIN is shown in Figures 8(a)8(d), averaged for 01:00 LST, 07:00 LST, 13:00 LST, and 19:00 LST. CIN values from 0 to -50 are considered weak, from -50 to -200 moderate, and $<-200$ strong. Throughout the year, the CIN tends to be moderately intense during the night, except during February-April, when the CIN decreases between -60 and -80 . Over the western side of the Andes and early in the morning, CIN is moderately intense during January-September and weak during October-December. Notwithstanding, CAPE values at this time are lowest in the Amazon side limiting the possibility of the development of MCSs. At 13:00 LST (Figure 8(c)), throughout the year, the $\mathrm{CIN}$ values at the west side of the PB are moderate but are weak between November and December, coinciding with the beginning of the rainy season in the coastal region. Similarly, the CIN values are weak, all year round, on the Amazonianinfluenced east side of the $\mathrm{PB}$, which together with the bimodal signal of CAPE might account for the afternoon convection. The CIN values at 19:00 LST (Figure 8(d)) are similar to the values obtained at 13:00 LST, which affects sides of the $\mathrm{PB}$ and throughout the year.

The situations depicted by the CAPE and CIN analyses may be conditioned by Omega. Figures 9(a)-9(d) show the Omega monthly climatology at 01:00 LST, 07:00 LST, 13:00 LST, and 19:00 LST. As it can be observed from Figures 9(a) 
TABLe 1: MCS's size $\left(\mathrm{km}^{2}\right)$ : 25th, 50th, and 75th percentiles by month.

\begin{tabular}{|c|c|c|c|c|c|c|c|c|c|c|c|c|c|}
\hline Percentile & Jan & Feb & Mar & Apr & May & Jun & Jul & Aug & Sep & Oct & Nov & Dec & Mean \\
\hline P25 & 2806 & 2867 & 3050 & 3050 & 3187 & 3050 & 2928 & 3142 & 3004 & 2928 & 2928 & 2867 & 2989 \\
\hline P50 & 4728 & 4758 & 5246 & 5002 & 5612 & 5246 & 4758 & 5734 & 5368 & 5368 & 5002 & 4514 & 5063 \\
\hline P75 & 11,605 & 10,797 & 12,444 & 11,163 & 12,292 & 13,939 & 10,919 & 12,109 & 12,444 & 12,154 & 11,041 & 9897 & 11,712 \\
\hline
\end{tabular}

and 9(d), a considerable modification of mesoscale features is the likely consequence of the ascendant air velocity in February to April at 01:00 and 19:00 LST. This fact may support the development of convective activity. On the contrary, much lower values of Omega ascending velocity are shown during the same months at 7:00 LST and 13:00 LST (Figures 9(b) and 9(c)). Interestingly, subsidence is present at 07:00 LST and 13:00 LST (Figures 9(b) and 9(c)) during June, July, and August, which is in agreement with the least active season of MCS development.

\subsection{Teleconnections for MCS Development in the Paute Basin}

5.3.1. Tropical Atlantic SST Influence on MCS Development. In Table 2, the statistics of the first 10 PCs are shown. The highest correlation (Pearson correlation 0.51) between MCS$\mathrm{E}$ and PC score time series is achieved with the 2nd PC, which accounts for $17.70 \%$ of the explained variance and together with the PC- 1 accounts for $40.25 \%$ of the explained variance. In Figure 10, the PC2 of the tropical Atlantic SSTA region $60^{\circ} \mathrm{W}$ to $10^{\circ} \mathrm{E}$ and $30^{\circ} \mathrm{N}$ to $30^{\circ} \mathrm{S}$ is presented. The spatial loading pattern of PC-2 depicts positive Atlantic SST anomalies from $5^{\circ} \mathrm{N}$ to $15^{\circ} \mathrm{S}$ (Figure 10). This pattern corresponds to the second varimax-rotated PC of Vuille et al. [30], with the first EOF of [33] and the EOF1 of [34] for the South Atlantic domain. This mode represents an in-phase SST response over the entire tropical South Atlantic with the strengthening and weakening of the subtropical anticyclone [34].

The normalized PC-2 score time series and detrended MCSE time series are shown in Figure 11(a). The normalized values greater/lower than 0.5/-0.5 standard deviations are shown. Values less than this threshold are set to zero. Important departures of MCS-E occurrence are especially during November 2001 and April 2008. Both events may be related to anomalous SST conditions in the tropical Pacific (Figure 11(b)). For instance, in November 2001, TNI registers 1.3 negative standard deviation anomaly, which is the second lower value behind June 2007 during the study period. For April 2008, TNI shows a positive anomalous value of 2.25 standard deviations, which belongs to the extremely wet episode in the coast of Ecuador [26]. Moreover, following Campozano et al. [11], extreme positive values of TNI imply wet conditions in Ecuador, whereas extreme positive values of Niño $1+2$ represent wet conditions in the coast and dry conditions in the Amazon; thus, both are Pacific competing influences for rainfall in Ecuador.

5.3.2. Tropical Pacific Influence on MCS Development. The influence of SST along the tropical Pacific on the MCS developed on the western region of the $\mathrm{PB}$ can be best
TABLE 2: Eigenvalues, percentage of the explained variance, and percentage of cumulative explained variables for 10 principal components, based on the principal component analysis of the tropical Atlantic region

\begin{tabular}{lccc}
\hline $\begin{array}{l}\text { Principal } \\
\text { component }\end{array}$ & Eigenvalue & $\begin{array}{c}\text { Explained } \\
\text { variance }(\%)\end{array}$ & $\begin{array}{c}\text { Cumulative explained } \\
\text { variance (\%) }\end{array}$ \\
\hline 1 & 0.0336 & 22.55 & 22.55 \\
$\mathbf{2}$ & $\mathbf{0 . 0 2 6 3}$ & $\mathbf{1 7 . 7 0}$ & $\mathbf{4 0 . 2 5}$ \\
3 & 0.0212 & 14.25 & 54.50 \\
4 & 0.0106 & 7.15 & 61.65 \\
5 & 0.0093 & 6.26 & 67.91 \\
6 & 0.0081 & 5.46 & 73.37 \\
7 & 0.0053 & 3.57 & 76.94 \\
8 & 0.0045 & 3.01 & 79.94 \\
9 & 0.0040 & 2.68 & 82.63 \\
10 & 0.0028 & 1.88 & 84.50 \\
\hline
\end{tabular}

Bold values indicate the highest correlation patterns with MCS-E.

illustrated by Figure 11(b). In Figure 11(b), the time series of TNI Fourier-detrended normalized anomalies and MCSnormalized detrended anomalies is shown (Pearson correlation 0.44 ). The normalized values greater/lower than $0.5 /-0.5$ standard deviations are shown. The contrasting patterns between the MCS-E and MCS-W (Figures 11(a) and 11(b)), respectively, are due to the different climatic influences on both sides of the Andes. Given that the effect of ENSO in Ecuador is mainly confined to the coastal area $[24,26]$, it is expected that, during ENSO phases, mainly MCS-W be affected. A clear sign of ENSO influence on MCS-W during the 2008 event is shown in Figure 11(b). The event of 2008, characterized by a cold central Pacific sea surface temperature and hot sea surface temperature along the east of the tropical Pacific, is typical for La Niña Modoki (LNM) [35]. On the contrary, Pearson correlation of MCS-W with SST Niño $1+2$ and Niño 3.4 is 0.119 and 0.130 , respectively, showing that MCS-W presents a much higher relation to the TNI ENSO index (Pearson correlation 0.44). Therefore, the increase of MCS-W may be related to an enhancement of convective conditions as a consequence of a positive SST gradient between east and west tropical Pacific, which may change the typical pattern of subsidence on the tropical eastern Pacific of the Walker circulation [35].

On the seminal study of Velasco and Fritsch [36], they used one year (05-1982/05-1983) of MCS data during an El Niño year. In South American midlatitudes, they found that, during the El Niño period, the number of MCCs was more than double the number than in the non-El Niño year (051982/05-1983), showing the impact of ENSO on MCC development. Moreover, they found an increase of MCS along the Peruvian coasts, due to the anomalous increase of SST in the Niño $1+2$ region. 


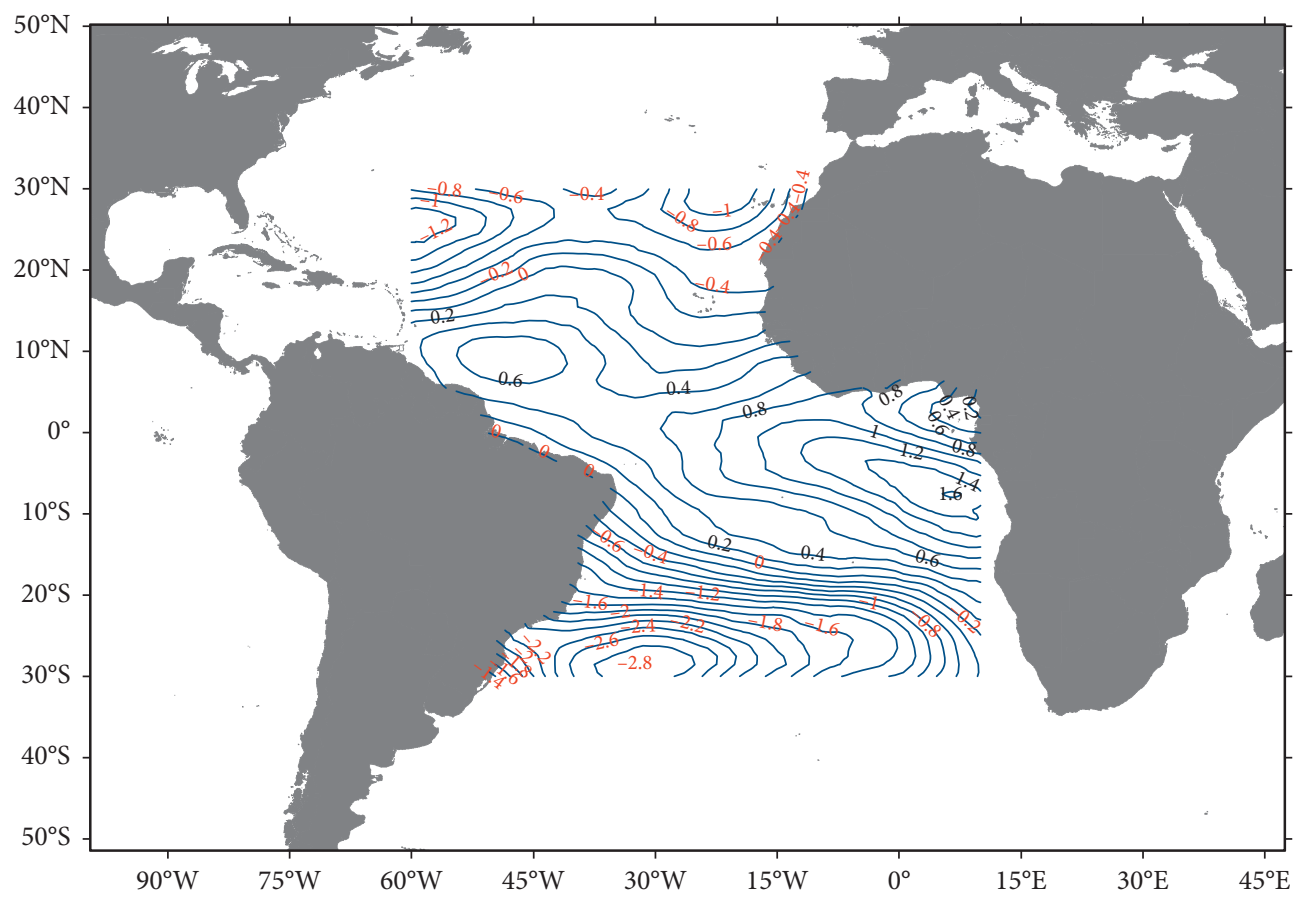

Figure 10: PC2 of the tropical Atlantic SSTA region $60^{\circ} \mathrm{W}$ to $10^{\circ} \mathrm{E}$ and $30^{\circ} \mathrm{N}$ to $30^{\circ} \mathrm{S}$.

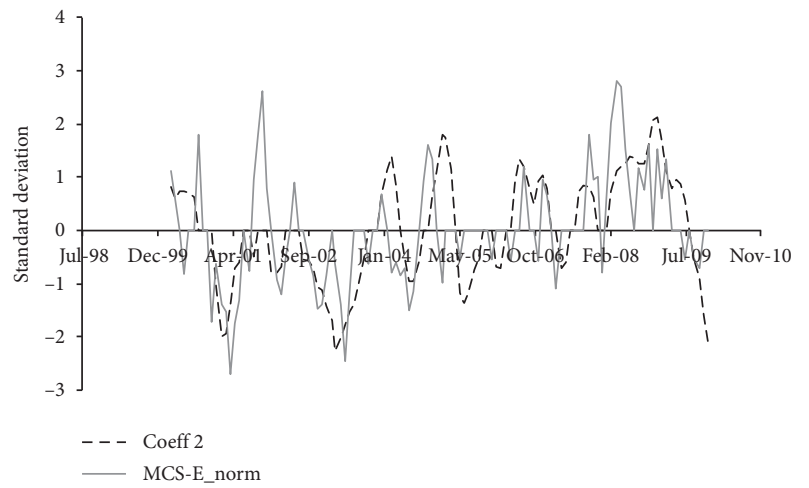

(a)

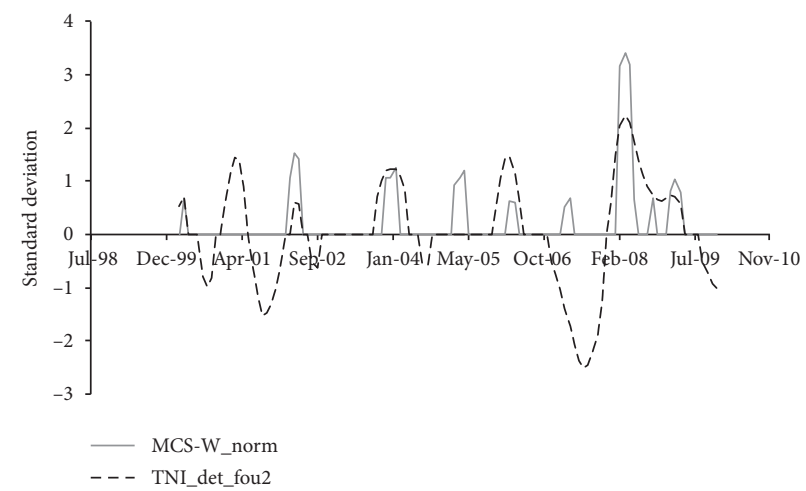

(b)

FIGURE 11: (a) 3-month moving average anomalies of MCSs monthly cumulative area east of the Paute basin (MCS-E_norm) and second principal component coefficients of tropical Atlantic SST from January 2000 to December 2009. (b) 3-month moving average anomalies of MCSs monthly cumulative area west of the Paute basin (MCS-W_norm) and 3-month moving average anomalies of Trans-Niño index detrended.

\section{Conclusions}

Mesoscale convective systems (MCSs) are related to large amounts of precipitation often inducing flash floods and raininduced landslides, with further negative impacts on the infrastructure and socioeconomic welfare. This paper examined the climatology of MCSs, the climatology of thermodynamic and dynamical variables, and teleconnections of MCS development in the Paute basin, an inter-Andean river basin in southern Ecuador.

The climatologic analysis of MCS occurrence shows a clear bimodal pattern, with higher occurrences of MCSs in March-April (MA) and October-November (ON), analogous with the bimodal character of the large-scale rainfall seasonality in the region. The easterlies are responsible for the basin preferentially receiving MCSs mainly from the east all year round, except during the El Niño periods when the number of MCSs developed in the coastal plains increases considerably. The diurnal cycle of the MCSs reveals a clear nocturnal occurrence of MCSs during both convectively active periods. Despite the fact that the MCS occurrence is bimodal, the seasonal distribution of the size of the MCSs remains almost constant throughout the year. The climatology of thermodynamic variables in the Amazon shows persistent high convective available potential energy and weak convective inhibition values from midday to 
nighttime, which seems to be related to the nocturnal formation of MCSs during MA and ON.

With respect to MCS teleconnections, the occurrence of MCS variability in the east of the Paute basin is positively correlated to the tropical Atlantic sea surface temperature south of the equator, linked to the strengthening and weakening of the Atlantic subtropical anticyclone. Main departures from this correlation are linked to anomalous conditions in the tropical Pacific, which are mainly related to ENSO. On the western side of the Paute basin, using the Trans-Niño index, it was shown that the MCSs developed on the west of the $\mathrm{PB}$ respond positively to the dynamics of ENSO, thus explaining, to a certain extent, the interannual variability of MCSs in the region of study.

\section{Data Availability}

The data used to support the findings of this study are available from the corresponding author upon request.

\section{Conflicts of Interest}

The authors declare that there are no conflicts of interest regarding the publication of this article.

\section{Acknowledgments}

The GridSat CDR used in this study was acquired from NOAA's National Climatic Data Center (http://www.ncdc. noaa.gov). This CDR was originally developed by Ken Knapp and colleagues for NOAA's CDR Program. The authors thank the German Research Foundation (DFG) for funding our project C12 in the framework of the PAK 823-825 "Platform for Biodiversity and Ecosystem Monitoring and Research in South Ecuador." The authors acknowledge DRI for their support (Mejia) in helping develop this manuscript.

\section{References}

[1] G. Poveda and O. Mesa, "Feedbacks between hydrological processes in tropical South America and large-scale oceanatmospheric phenomena," Journal of Climate, vol. 10, no. 1981, pp. 2690-2702, 1997.

[2] R. D. Garreaud, M. Vuille, R. Compagnucci, and J. Marengo, "Present-day South American climate," Palaeogeography, Palaeoclimatology, Palaeoecology, vol. 281, no. 3-4, pp. 180-195, 2009.

[3] L. Jaramillo, G. Poveda, and J. Mejía, "Mesoscale convective systems and other precipitation features over the tropical Americas and surrounding seas as seen by TRMM," International Journal of Climatology, vol. 37, pp. 380-397, 2017.

[4] R. A. Houze Jr., Cloud Dynamics, Academic Press, San Diego, CA, USA, 1995.

[5] R. A. Houze Jr., "Mesoscale convective systems," Reviews of Geophysics, vol. 42, no. 4, pp. 1-43, 2004.

[6] H. W. Kim and D. K. Lee, "An observational study of mesoscale convective systems with heavy rainfall over the Korean Peninsula," Weather and Forecasting, vol. 21, no. 2, pp. 125-148, 2006.

[7] J. Bendix and W. Lauer, "Die Niederschlagsjahreszeiten in Ecuador und ihreklimadynamische Interpretation," Erdkunde, vol. 46, pp. 118-134, 1992.

[8] T. Eichler, W. Higgins, T. Eichler, and W. Higgins, "Climatology and ENSO-related variability of North American extratropical cyclone activity," Journal of Climate, vol. 19, no. 10, pp. 2076-2093, 2006.

[9] R. V. Andreoli, R. A. Ferreira de Souza, M. T. Kayano, and L. A. Candido, "Seasonal anomalous rainfall in the central and eastern Amazon and associated anomalous oceanic and atmospheric patterns," International Journal of Climatology, vol. 32, no. 8, pp. 1193-1205, 2012.

[10] T. J. Killeen, M. Douglas, T. Consiglio, P. M. Jørgensen, and J. Mejia, "Dry spots and wet spots in the Andean hotspot," Journal of Biogeography, vol. 34, no. 8, pp. 1357-1373, 2007.

[11] L. Campozano, R. Célleri, K. Trachte, J. Bendix, and E. Samaniego, "Rainfall and cloud dynamics in the Andes: a Southern Ecuador case study," Advances in Meteorology, vol. 2016, Article ID 3192765, 15 pages, 2016.

[12] C. F. Angelis, G. R. McGregor, and C. Kidd, "A 3-year climatology of rainfall characteristics over tropical and subtropical South America based on tropical rainfall measuring mission precipitation radar data," International Journal of Climatology, vol. 24, no. 3, pp. 385-399, 2004.

[13] K. Trachte, R. Rollenbeck, and J. Bendix, "Nocturnal convective cloud formation under clear-sky conditions at the eastern Andes of south Ecuador," Journal of Geophysical Research, vol. 115, no. D24203, 2010.

[14] J. Bendix, K. Trachte, J. Cermak, R. Rollenbeck, and T. Nauß, "Formation of convective clouds at the foothills of the tropical eastern Andes (South Ecuador)," Journal of Applied Meteorology and Climatology, vol. 48, no. 8, pp. 1682-1695, 2009.

[15] W. Buytaert and B. De Bievre, "Water for cities: the impact of climate change and demographic growth in the tropical Andes," Water Resources Research, vol. 48, no. 8, 2012.

[16] W. Buytaert, R. Celleri, P. Willems, B. De Bièvre, and G. Wyseure, "Spatial and temporal rainfall variability in mountainous areas: a case study from the south Ecuadorian Andes," Journal of Hydrology, vol. 329, no. 3-4, pp. 413-421, 2006.

[17] R. Celleri, P. Willems, W. Buytaert, and J. Feyen, "Space-time rainfall variability in the Paute basin, Ecuadorian Andes," Hydrological Processes, vol. 21, no. 24, pp. 3316-3327, 2007.

[18] J. Espinoza, J. Ronchail, L. Guyot et al., "Spatio-temporal rainfall variability in the Amazon basin countries (Brazil, Peru, Bolivia, Colombia)," International Journal of Climatology, vol. 29, no. 11, pp. 1574-1594, 2009.

[19] J. Bendix, "Precipitation dynamics in Ecuador and northern Peru during the 1991/92 El Niño: a remote sensing perspective," International Journal of Remote Sensing, vol. 21, no. 3, pp. 533-548, 2000.

[20] K. R. Knapp and NOAA CDR Program, NOAA Climate Data Record (CDR) o of Gridded Satellite Data from ISCCP B1 (GridSat-B1) 11 Micron Brightness Temperature, Version 2, NOAA National Climatic Data Center, Asheville, NC, USA, 2014.

[21] A. Rehbein, T. Ambrizzi, and C. R. Mechoso, "Mesoscale convective systems over the Amazon basin. Part I: climatological aspects," International Journal of Climatology, vol. 38, no. 1, pp. 215-229, 2018.

[22] J. Bendix, R. Rollenbeck, and W. E. Palacios, "Cloud detection in the Tropics-a suitable tool for climate-ecological studies in the high mountains of Ecuador," International Journal of Remote Sensing, vol. 25, no. 21, pp. 37-41, 2004.

[23] M. Ishii, A. Shouji, S. Sugimoto, and T. Matsumoto, "Objective analyses of sea-surface temperature and marine meteorological variables for the 20th century using ICOADS and the Kobe Collection," International Journal of Climatology, vol. 25, no. 7, pp. 865-879, 2005.

[24] F. Rossel, R. Mejía, G. Ontaneda et al., "Régionalisation de l'influence du el Niño sur les précipitations de l'Équateur," 
Bulletin de l'Institut Français d'Études Andines, vol. 27, no. 3, pp. 643-654, 1998.

[25] G. P. Compo, J. S. Whitaker, and P. D. Sardeshmukh, "Feasibility of a 100 year reanalysis using only surface pressure data," Bulletin of the American Meteorological Society, vol. 87, pp. 175-190, 2006.

[26] J. Bendix, K. Trache, E. Palacios et al., "El Niño meets La Niña-anomalous rainfall patterns in the "traditional" El Niño region of southern Ecuador," Erdkunde, vol. 65, no. 2, pp. 151-167, 2011.

[27] D. Mora and P. Willems, "Decadal oscillations in rainfall and air temperature in the Paute River Basin-Southern Andes of Ecuador," Theoretical and Applied Climatology, vol. 108, pp. 267-282, 2012.

[28] L. Campozano, D. Ballari, and R. Célleri, "Imágenes TRMM para identificar patrones de precipitación e índices ENSO en Ecuador," MASKANA, vol. 5, pp. 185-191, 2014.

[29] K. E. Trenberth and D. P. Stepaniak, "Indices of El Niño evolution," Journal of Climatology, vol. 14, no. 8, pp. 16971701, 2001.

[30] M. Vuille, R. Bradley, and F. Keimig, "Climate variability in the Andes of Ecuador and its relation to tropical Pacific and Atlantic sea surface temperature anomalies," Journal of Climate, vol. 13, no. 14, pp. 2520-2535, 1999.

[31] R. S. Padrón, B. P. Wilcox, P. Crespo, and R. Célleri, "Rainfall in the Andean Páramo: new insights from high-resolution monitoring in Southern Ecuador," Journal of Hydrometeorology, vol. 16, no. 3, pp. 985-996, 2015.

[32] U. Romatschke and R. A. Houze Jr., "Characteristics of precipitating convective systems accounting for the summer rainfall of tropical and subtropical South America," Journal of Hydrometeorology, vol. 14, no. 1, pp. 25-46, 2013.

[33] D. B. Enfield and D. A. Mayer, "Tropical Atlantic SST variability and its relation to El Niño-Southern Oscillation," Journal Geophysical Research, vol. 102, pp. 929-945, 1997.

[34] S. A. Venegas, L. Mysak, and D. Straub, "Evidence for interannual and interdecadal climate variability in the South Atlantic," Geophysical Research Letters, vol. 23, no. 19, pp. 2673-2676, 1996.

[35] K. Ashok, S. K. Behera, S. A. Rao, H. Weng, and T. Yamagata, "El Niño Modoki and its possible teleconnection," Journal of Geophysical Research: Oceans, vol. 112, no. 11, pp. 1-27, 2007.

[36] I. Velasco and J. M. Fritsch, "Mesoscale convective complexes in the Americas," Journal of Geophysical Research, vol. 92, no. D8, pp. 9591-9613, 1987. 

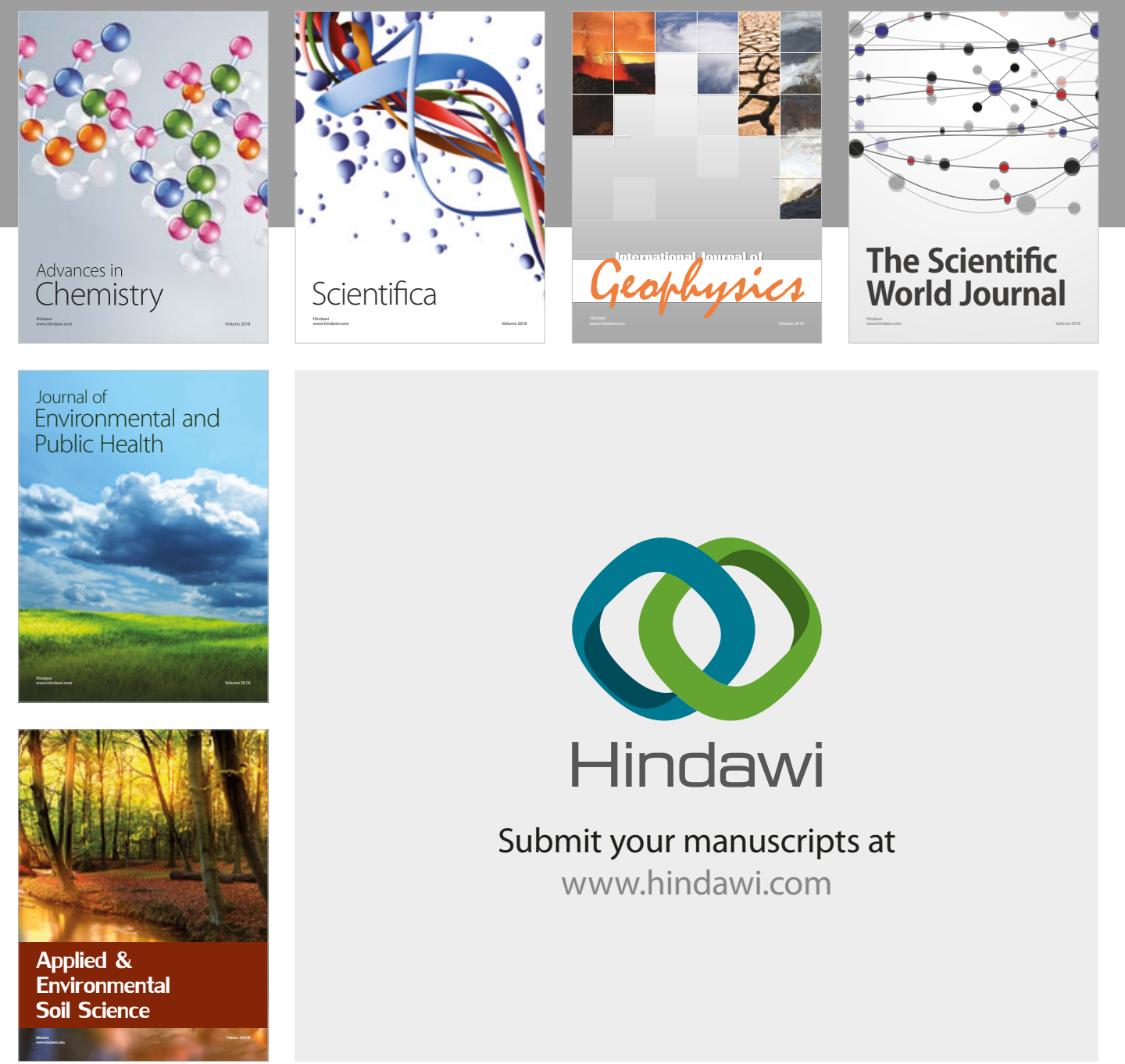

The Scientific

\section{World Journal}
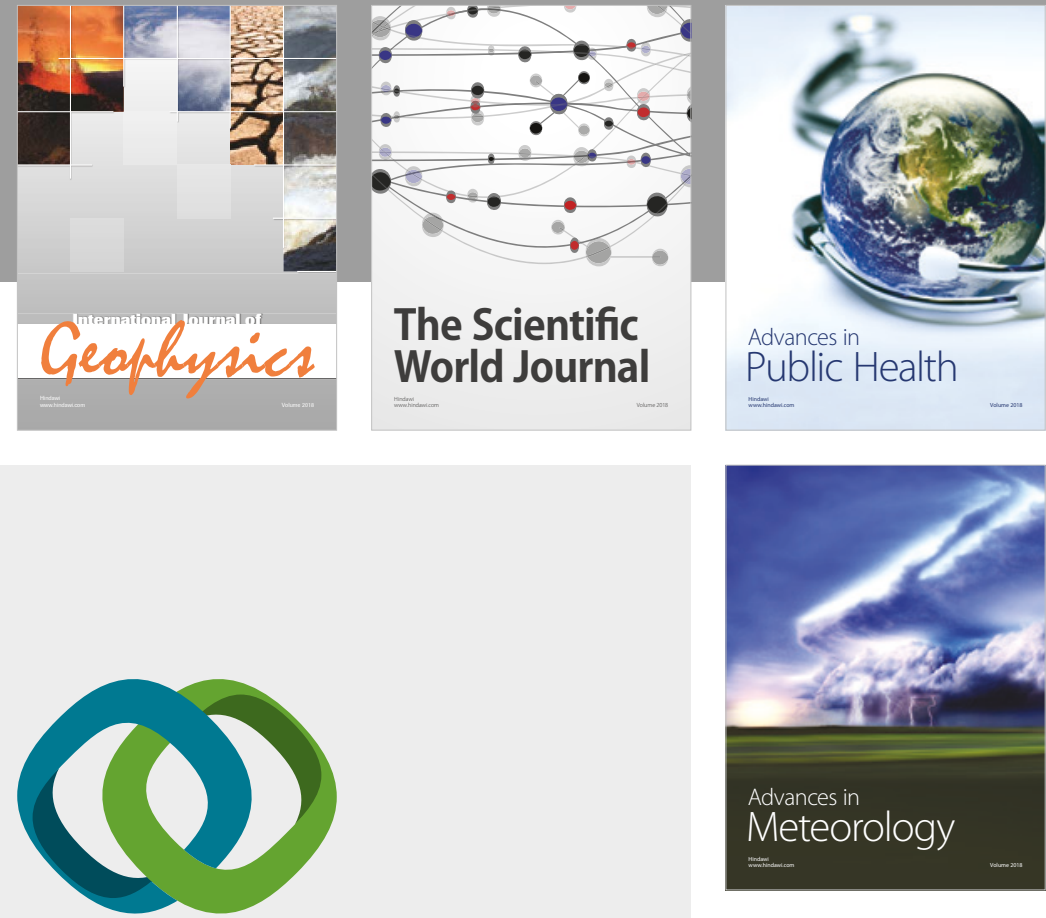

Advan

Public Health

\section{Hindawi}

Submit your manuscripts at

www.hindawi.com
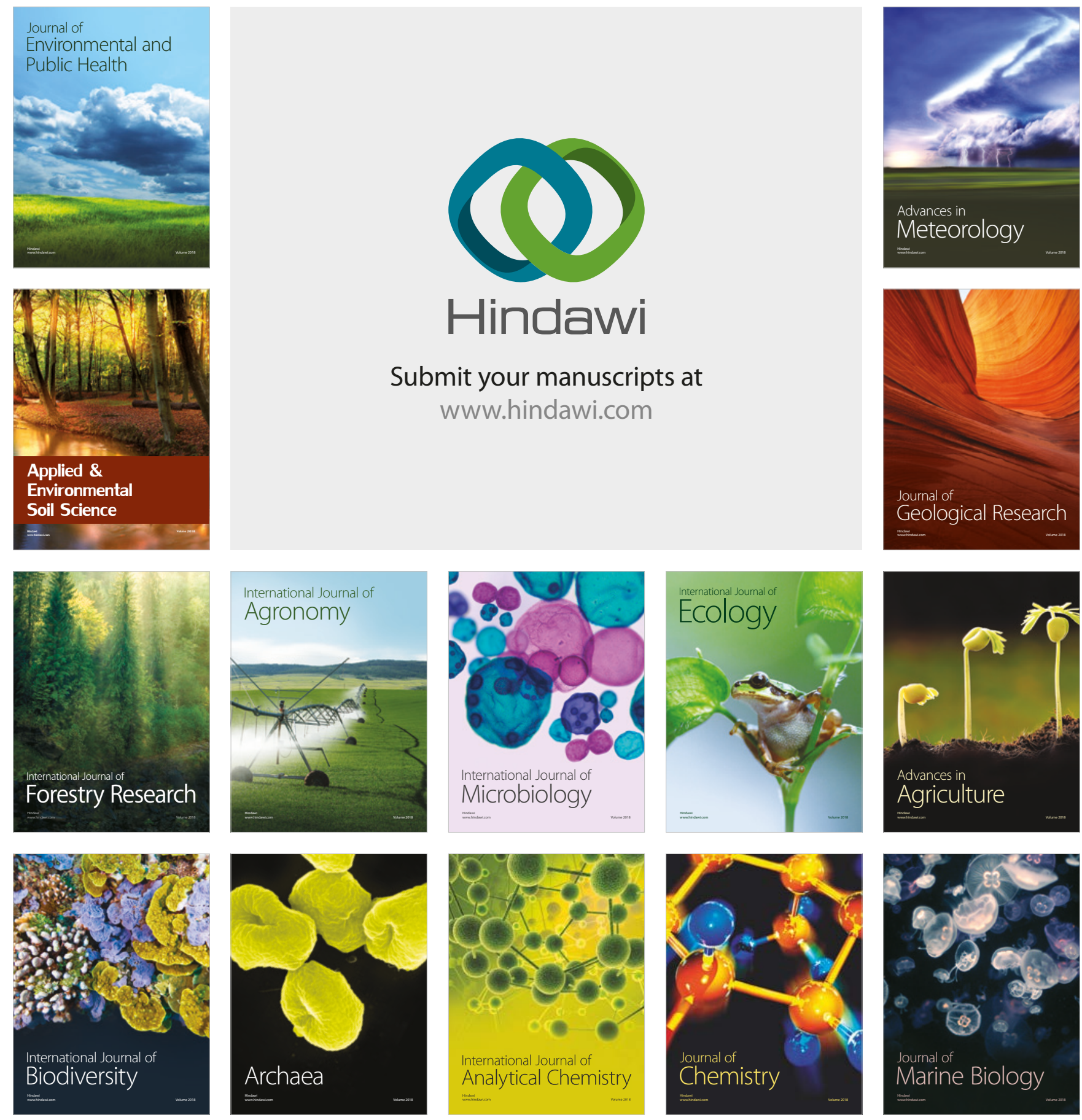